\title{
Global biomass trade for energy - Part 1: Statistical and methodological considerations
}

Svetlana Proskurina ${ }^{a^{*}}$, Martin Junginger ${ }^{b}$, Jussi Heinimö ${ }^{c}$ \& Esa Vakkilainen ${ }^{a}$

${ }^{\text {a }}$ Lappeenranta University of Technology, Skinnarilankatu 34, 53850 Lappeenranta, Finland

b Copernicus Institute of Sustainable Development, Heidelberglaan 2, 3584 CS Utrecht, The Netherlands

${ }^{\mathrm{c}}$ Mikkeli Development Miksei Ltd, Sammonkatu 12, 50130 Mikkeli, Finland

* Corresponding author. Tel.: +358466322953.

E-mail addresses: svetlana.proskurina@lut.fi, proskurina.s@mail.ru (S. Proskurina).

Postal address: LUT, P.O. Box 20, FIN-53851 Lappeenranta, Finland.

\begin{abstract}
:
Many countries have limited low-cost biomass resources to satisfy their own demand for bioenergy. International trade of biomass in various solid and liquid forms is consequently increasing. The aim of this study is to present a quantitative overview of the development of international biomass trade for energy purposes including the discussion of methodological issues. The paper focuses on the production, export and import of solid and liquid biofuels, including industrial roundwood, wood chips, fuel wood, wood pellets, biodiesel and bioethanol. The study highlights changes in trends that have occurred over the past decade. Trade on global bioenergy markets is increasing: total trade of biomass for energy purposes is estimated as having increased twofold from around $780 \mathrm{PJ}$ in 2004 to $1250 \mathrm{PJ}$ in 2015. Despite the importance of the bioenergy market and the growth of biomass trade for energy, accurate evaluation of energy-related biomass trade faces a number of methodological challenges, such as uncertainties in international statistics, inconsistent data regarding export and import volumes, as well as limited information about the final use of traded products.
\end{abstract}

Keywords: international trade; biomass market; biofuels; bioenergy; forestry; biomass use 


\section{INTRODUCTION}

Biomass is one of the world's more important renewable and sustainable energy sources. In addition to direct burning to obtain energy, biomass can serve as a feedstock for conversion into various liquid and solid fuels (biofuels). Biofuels, unlike many other renewable energy forms, can be transported and stored, permitting heat and power generation on demand, which is a key characteristic in an energy mix with a high dependence on intermittent sources such as wind and solar power. ${ }^{1}$ The many advantageous characteristics of biomass, together with increasing energy demand, a need for climate change mitigation measures and a desire to decrease dependence on fossil fuels have led countries around the world to show greater interest in development of the bioenergy sector. Many countries, however, have limited biomass resources to satisfy their own bioenergy needs, whereas others produce a considerable biomass surplus. Thus, international trade in bioenergy products in solid and liquid form has become increasingly important, particularly in continuously expanding markets such as markets for wood pellets, biodiesel and bioethanol.

Biomass can be traded directly and indirectly for energy purposes. Indirect trade refers to biomass that is traded primarily for a material purpose (e.g. roundwood to be processed into sawnwood in the destination country), of which a fraction ultimately ends up being utilised for energy through the use of processing residues (e.g. sawdust). For example, Finland imports large amounts of raw wood, such as logs, pulpwood and chips, from Russia for material production. However, during the manufacturing processes of the primary products, a significant part (typically 40-60\%) ends up being used for energy purposes or is converted into by-products that are utilized in energy perposes. ${ }^{2}$ It should be noted that imported biomass may additionally end up as tertiary post-consumer product (e.g. demolition wood) and may thus ultimately contribute further to bioenergy purposes in the importing country. Several studies ${ }^{2,3,4,5,6}$ have presented analyses of international trade in biomass, many initiated by Task $40^{7}$ of the International Energy Agency (IEA) Bioenergy Technology Collaboration Programme. IEA Bioenergy Task $40^{7}$ focuses on international bioenergy technology potential, bioenergy utilization barriers and trade, as well as their wider implications. In 2007, Heinimö and Junginger ${ }^{2}$ presented a first overview of the global status of production and trade of biomass for energy, considering the period 2004-2006. This study - one of the few - also assessed indirect biomass trade for energy. In the last 10 years, trade of biomass for energy has been growing sharply, and an update of the study is thus required.

A number of recent studies have been presented that investigate trade in biomass, they have, however, tended to focus on direct trade of bioenergy. For example, Lamers et al. ${ }^{8}$ assess a bottom-up global trade model for analysing future solid and liquid biomass trade. A review of past developments in liquid ${ }^{4}$ and solid ${ }^{3}$ biofuels markets is presented by Lamers et al. Goh et al. ${ }^{5}$ describe the global wood pellets market. Matzenberger et al. ${ }^{9}$ show bioenergy trade models and market scenarios for future perspectives of international bioenergy trade. Goh et al. ${ }^{6}$ investigated the sustainability of traded biomass flows, mostly for the Netherlands. Assessing the international biomass trade for bioenergy in the context of renewable energy deployment scenarios for the EU-27, Hoefnagels et al. ${ }^{10}$ suggest that the share of imported biomass is likely to increase. The above studies mostly focus on direct trade and specific products, e.g. wood pellets, or specific regions, such as the Netherlands and the EU, rather than providing a global biomass trade overview. Despite the significant number of studies, 
there is no comprehensive and up-to-date overview of the current state of international biomass trade covering recent developments in the major biomass commodities traded. Thus, work is required that updates and extends the findings of earlier studies.

In view of the breadth of the topic, this study is presented as two independent papers. The aim of this paper is to update total figures on direct and indirect international trade of biomass for energy purposes by presenting export and import of bioenergy-related biomass as well as the estimated scale of international trade. Moreover, the study examines a number of methodological issues in evaluation of energy-related biomass trade. With regard to analysis of indirect trade in biomass, the study aims to enhance the method developed by members of Task 40 through analysis of the final applications of traded biomass and discussion of most recent changes in global biomass trade for energy purposes. The second paper, ${ }^{11}$ which is also presented in this issue, "Global biomass trade for energy: Part 2 - production and trade streams" focuses on the production of the products studied by country and presents analysis of the main global trade streams as well as emerging trade streams.

The study covers indirect trade of wood chips, wood particles and industrial roundwood, and direct trade of products such as charcoal, fuel wood, wood pellets, biodiesel, bioethanol and palm oil. Table 1 lists biomass products that are included in and excluded from the study. The paper specifically focuses on gross volumes of direct and indirect energy biomass trade until 2015 and presents development trends of trade in energy biomass for the period 2004-2015.

Table 1: Biomass products

\begin{tabular}{|l|l|}
\hline $\begin{array}{l}\text { Biomass products included in the } \\
\text { study }\end{array}$ & Biomass products excluded from the study \\
\hline $\begin{array}{l}\text { Direct trade: charcoal, fuel wood, } \\
\text { wood pellets, bioethanol, biodiesel, } \\
\text { palm oil, }\end{array}$ & $\begin{array}{l}\text { used cooking oil, starch and sugar crops, wood } \\
\text { waste, municipal solid waste, biochar, bio-jet fuel, } \\
\text { torrefied biomass, torrefied pellets, pyrolysis oil, } \\
\text { Indirect trade: wood chips and } \\
\text { particles, industrial roundwood }\end{array}$ \\
$\begin{array}{l}\text { sanflower oil, soy oil), oil seeds (e.g. rapeseed, soy } \\
\text { sunflow, } \\
\text { beans), barley, wheat, maize, pulp and paper }\end{array}$ \\
\hline
\end{tabular}

Several agricultural products are related to bioenergy, and agricultural crops are the globally dominant feedstocks for ethanol and biodiesel production. ${ }^{7}$ For example, $152 \mathrm{Mt}$ of maize and about 9 Mt of wheat are used annually for biofuels. ${ }^{12}$ Soybeans provide the major feedstock for biodiesel production in many countries, such as Argentina and Brazil. Portugal uses about $49 \%$ soybean oil, which comes mostly from imports from Brazil, in feedstock for its biodiesel production. Soy is mainly produced for animal feed, and it is the by-products that are used for oil and biodiesel production.

The study excludes some forestry and agricultural products due to the difficulty of differentiating whether they are traded for energy or other purposes. Moreover, some agricultural products are excluded in order to avoid double counting, which can occur if, for example, soybeans are used as a feedstock for biodiesel production.

Industrial roundwood is defined as all industrial wood in the rough (sawlogs and veneer logs, pulpwood and other industrial roundwood). ${ }^{13}$ Fuel wood is defined as wood in the rough (from trunks and branches of trees) to be used as fuel for purposes such as cooking, heating and power production. Wood remains an important fuel resource for domestic heating and 
cooking in many developing countries, and wood fuel provides more than half of the energy supply in 29 countries, many of which are in sub-Saharan Africa. Worldwide, about $50 \%$ of wood production is used for energy. ${ }^{14}$

\section{METHOD}

Finding reliable data is a challenge when quantifying bioenergy trade flows. IEA Task $40^{7}$ suggests that despite a multitude of international authorities, agencies, institutions and enterprises compiling and publishing biomass and biomass product statistics, figures on the international biofuels trade that are available directly from international statistics, in practice, still contain substantial uncertainties. In this study, in order to identify the most realistic trade flows, the volumes of traded biomass were checked from several sources. ${ }^{13,15-18}$ The study also analysed information from available open publications ${ }^{19,20-24}$ as well as via discussions with experts ${ }^{25,26}$ from the bioenergy industry. This study furthermore canvassed expert and stakeholder opinions ${ }^{26,27}$ about the applied methodology.

Indirect trade cannot be assessed directly via trade statistics and requires detailed examination of biomass flows as well as conversion patterns. In most cases, trade statistics do not give information about the final use of products, which moreover can be different in different countries. Some biomass products are traded for material purposes, yet ultimately end up being used for energy purposes. Thus, by-products from wood processing industry from the upgrading industry, which uses sawn timber as raw material, are the main raw material for the wood pellet industry. ${ }^{28}$ For example, in Finland, sawdust is the main raw material for wood pellets production. ${ }^{29}$

\subsection{Complexity of biomass streams}

International biomass trade includes a significant number of cross-border streams. Biomass is traded under different headings, such as various end-use purposes, and in different forms, such as raw, processed, or final products. Thus, trade streams constitute a complex field and examination of the international biofuel trade becomes complicated. Imported biomass or a product that includes imported biomass can be processed in the imported country into more refined final products, which are then consumed within the country or exported forward. Liquid biofuels constitute one of the largest areas of new demand for agricultural products, and they play an important role on commodity markets and are expected to continue to be important in the foreseeable future. ${ }^{28}$

If the entirety of all biomass trade streams, that is, all forest products ${ }^{1}$, agricultural products and biodegradable wastes, were to be investigated until the carbon they contain is oxidised into $\mathrm{CO}_{2}$, this review would become unwieldy and overly complex. Consequently, the study focuses only on the most significant biomass streams from the bioenergy perspective: 1) biofuels (products that are traded for energy purposes, such as production of fuel ethanol, wood pellets and firewood); and 2) raw wood ${ }^{2}$ (wood matter that is used in the manufacture of forest products), a part of which ends up for energy purposes (indirect trade, see section 3).

\footnotetext{
${ }^{1}$ A forest product refers to any material derived from forestry for direct consumption or commercial use, such as lumber, paper, or forage for livestock

${ }^{2}$ Raw wood refers to roundwood (domestic and imported) and imported (non-domestic) wood chips used as raw material in the forest industry
} 


\subsection{Statistical uncertainties and sensitivity}

In this study, the estimated volumes of international trade of studied products between 20042015 were calculated as average values of export and import figures indicated in trade statistics ${ }^{13,15-17}$ and other sources such as previous publications, ${ }^{30,31}$ reports, ${ }^{19,21,32,33}$ country statistics $^{18,22}$ and expert opinions. ${ }^{25,26,27}$ In an ideal situation, world imports are equal to world exports. However, this is often not the case. For example, reported values of export and import of biodiesel, ethanol, wood fuels, charcoal, and wood chips and particles can deviate by $30 \%, 40 \%, 10 \%, 15 \%$ and $20 \%$, respectively. There are numerous reasons for these discrepancies; for instance, countries can use different trade systems and quality measurements. Although some countries report gross weight and some report net weight, most major reporting parties, such as the USA, China and the EU, report net weight. ${ }^{15}$ Furthermore, time lags can occur when, for example, exports are registered in one year and the corresponding import in the following year. In addition, there are different threshold levels for reporting, and commodities may, erroneously or deliberately, be registered under a wrong HS code. Finally, misallocation from reporting countries because of re-exports and confidentiality can accrue, e.g., in reporting of biodiesel and ethanol trade. ${ }^{34}$ For the above reasons, import and export averages are represented with deviation, which is shown in brackets in the estimated scale of international biomass trade evaluation (Section 4.2).

For ethanol and biodiesel, data were taken from OECD-FAO Agricultural Outlook. ${ }^{16}$ This source explains the deviation between exports and imports by corresponding statistical differences. To improve the reliability of the international biomass analysis, the study identified the share of ethanol that is used for energy purposes from total traded volumes, ${ }^{13,15,17}$ which have approximated estimations due to the inclusion of statistics of countries that do not differentiate between imported ethanol used for biofuels and for other purposes. $^{13,15-17,33}$

For wood pellets, values may differ because some trade deals could have been cancelled and because of categorization differences. Since 2012, Eurostat has used one international pellet code, whereas previously, during 2009-2012, European statistics used a specific trade code "sawdust and wood waste scraps, agglomerated in pellets". Prior to 2009, wood pellet trade was documented in Eurostat under the trade code for "wood waste \& scrap" or "sawdust," both stating "whether or not agglomerated in logs, briquettes, pellets or similar". ${ }^{19}$

For palm oil, the study only considers the share of palm oil that is used for energy purposes. In the statistical data, there is no clear separation between industrial and food usages of palm oil; thus, palm oil for energy purposes was calculated based on the total EU domestic industrial consumption minus use for the chemical industry. ${ }^{16,17,35}$ Palm oil usage in the rest of the world is excluded from the study because, outside Europe, palm oil is used mostly for the food and chemical industries. Excluding the EU, the main global importers of palm oil are China and India, ${ }^{15}$ where the share of palm oil used for energy is negligible. In India and China, respectively, $90 \%{ }^{36}$ and $70 \%{ }^{37}$ of imported palm oil is used in the food industry and the remainder is mostly used in the chemical industry. ${ }^{36,37}$

In discussion of indirect trade, assumptions are made regarding the final application of products such as roundwood and its by-products. To improve the methodology of previous studies, ${ }^{30,38}$ indirect international biomass trade evaluation is extended by more rigorous calculation of the conversion factor. In previous study by Heinimö et al., ${ }^{30,38}$ the conversion 
factor, which refers to the percentage of roundwood, wood chips and particles created as byproducts after primary usage that is used for energy purposes, was calculated only for the EU and only based on the Finnish forest industry. In studies by Heinimö et al., ${ }^{30,38}$ the conversion factors from raw wood into by-products that end up in energy purposes were defined based on studying wood flows in Finnish forest industry and were used as universal conversion factors for the whole word. In this study, in addition to the Finnish case, values for Germany are taken into consideration in calculation of the EU figures. In 2014, the main EU leaders in roundwood imports were two Nordic countries, Sweden $\left(8 \mathrm{Mm}^{3}\right)$ and Finland $\left(6 \mathrm{Mm}^{3}\right)$, and two countries from Central Europe, Austria $\left(7 \mathrm{Mm}^{3}\right)$ and Germany $\left(8 \mathrm{Mm}^{3}\right){ }^{13}$ Thus, the conversion factor is calculated based on German and Finnish data, as representative countries from two different EU regions. Additionally, the study calculates an assumed conversion factor for China, because worldwide it is the major consumer of imported roundwood. ${ }^{22}$ As a result, the average conversion factor for estimation of global trade is calculated as the average between the EU and China, which globally are the main importers of industrial roundwood. ${ }^{13}$ In addition, these study extends the previous studies by presenting as variation between export and import volumes of studied products.

\section{INDIRECT TRADE ESTIMATION}

As mentioned earlier, indirect trade is defined as the biomass fractions traded primarily for material purposes that ultimately end up in energy through usage of process residues (e.g. sawdust). Indirect trade can encompass many products. For example, exported paper or cardboard can return to the producing country within packaged products and later be utilised for energy purposes such as recovery fuel or biogas. Large amounts of agro-residues, such as rice husk, potato peels, coconut shells, banana peels, shells of all kinds of nuts (peanuts, walnut, cashew etc.) may end up being used for bioenergy in an importing processing country. Estimation of the volume of agro-residues traded for energy is thus difficult due to limited knowledge about final applications. Additionally, such trade is minor compared with, for example, roundwood trade, and thus, trade in agro-residues is excluded from the study. Detailed analysis of the total supply chain from traded volumes to final waste utilization could be a topic of interest for future studies.

In our study, wood chips and particles as well as industrial roundwood are allocated to the category of indirect trade. Trade in wood chips mostly occurs in conjunction with pulp and paper production. The conversion factors of roundwood are also tenable for indigenous wood chips and particles. Due to limited knowledge about indirect trade assessment and the large spectrum of possible applications for wood chips and particles, the study focuses on indirect trade of industrial roundwood, whose conversion factor is applied to wood chips and particle trade. In our study the conversion factor for roundwood is estimated without bark. However, in many statistics, roundwood includes bark. In case of the estimation of conversion factors for bark-free wood chips and for roundwood that includes bark, the conversional factor can not be applicable to both. Moreover, traded volumes of industrial roundwood are larger than wood chips and particles, which are mostly used locally or traded over short distances.

The global industrial roundwood trade is considerable. ${ }^{13}$ The largest importers of industrial roundwood are China and the EU. ${ }^{13,15}$ Interestingly, during the last 5 years, China increased industrial roundwood imports, ${ }^{13}$ while imports into the EU fluctuated (Figure 1). ${ }^{17}$ According 
to Eurostat, ${ }^{17}$ in the EU-28, approximately $0.25 \%$ of roundwood production is used directly as wood for fuel. This percentage varies in different countries. For example, in the Netherlands, only $0.1 \mathrm{Mm}^{3}$ of low quality logs of the total $1.1 \mathrm{Mm}^{3}$ harvest is used for residential heating. In Nordic countries, these volumes can be larger. Additionally, by-products from roundwood use can be used as energy wood. For example, the logs can be chipped for combined heat and power plants or indirectly as feedstock for pulp. In addition to roundwood logs, also a part of sawn logs can be used for energy, as conversion of chips or sawdust remaining after the wood processing steps.

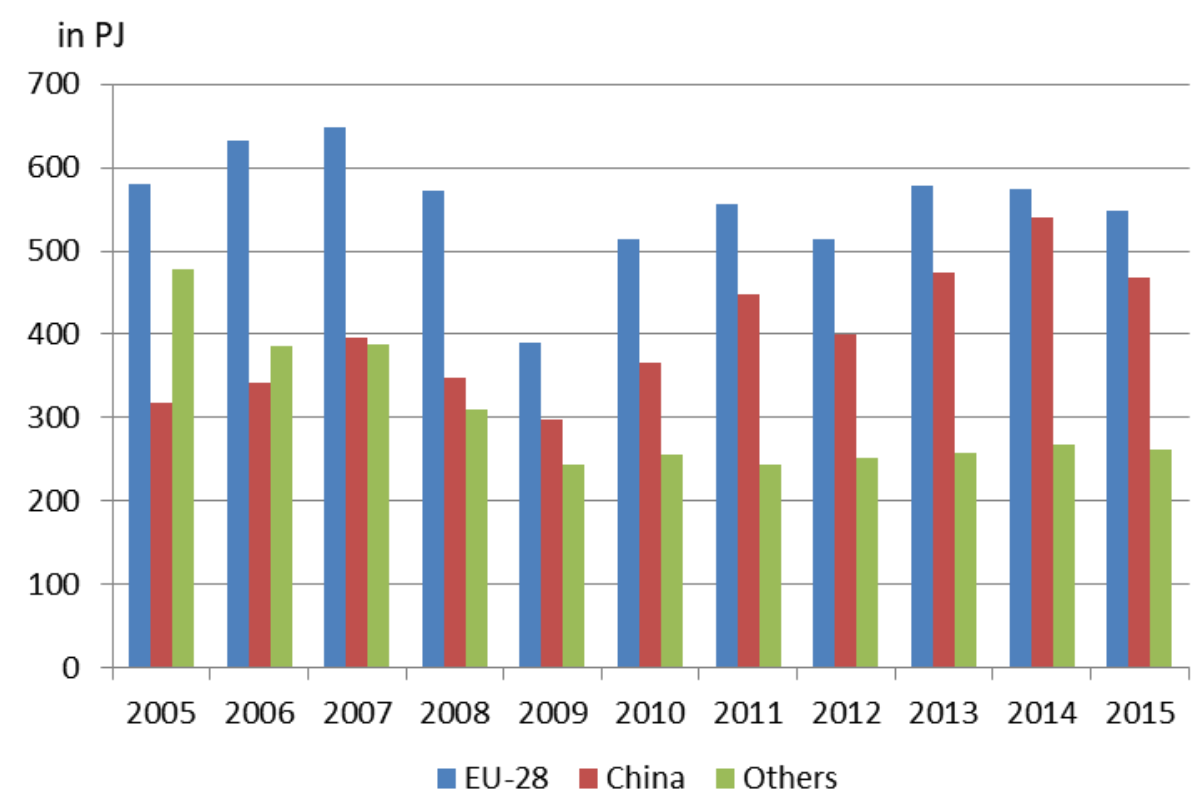

Figure 1. Total imports of industrial roundwood during 2005-2015. Data was obtained from ${ }^{13}$ and for EU-28 from ${ }^{17}$. (Density is $0.8 \mathrm{t} / \mathrm{m}^{3,} 10 \%$ bark added, cal val. $=9.4 \mathrm{GJ} / \mathrm{t}$.)

Trade flow data for industrial roundwood was taken from FAOSTAT, that is, the data collection of the Food and Agriculture Organization of the United Nations (FAO). ${ }^{13}$ In FAOSTAT, industrial roundwood is defined as sawlogs, pulpwood and other roundwood. Industrial roundwood trade, from the bioenergy trade evaluation perspective, can be considered indirect trade because the primary purpose of industrial roundwood use is mostly realized as raw material for the forest products industry and a part of the by-products, such as bark, black liquor, sawdust and chips, is used as fuel for energy purposes. Investigation of industrial roundwood for energy purposes is challenging. In the forest industry, around 40$60 \%$ of roundwood can be converted into forest products. The rest ends up as by-products such as black liquor, bark, sawdust and chips, which have no feasible direct material use within the traditional forest products industry. The conversion efficiency of raw wood varies between the different production processes for different products (Table 2). In addition, the level of technology applied and level of integration of the production process affects the conversion efficiency. For example, mechanical wood processing can convert wooden raw material into products more efficiently than chemical pulp making. ${ }^{25}$

Table 2. Parameters used in the model of wood streams in the Finnish forest industry presented by Heinimo ${ }^{30}$ for wood conversion into products and material by-products. 


\begin{tabular}{|l|c|}
\hline Branch of forest industry & $\begin{array}{c}\text { Wood conversion into products from } \\
\text { the wood input stream }\end{array}$ \\
\hline Plywood mills & $36 \%$ \\
\hline Particle- and fibreboard mills & $99 \%^{\mathrm{b})}$ \\
\hline Other mechanical wood processing & $35 \%^{\mathrm{a})}$ \\
\hline Chemical pulp mills & $52 \%$ \\
\hline Sawmills & $45 \%^{\mathrm{a})}$ \\
\hline Mechanical and semi-mechanical pulp mills & $90 \%{ }^{\mathrm{b})}$ \\
\hline${ }^{\text {a) }}$ Realised conversion in 2013 from Finnish forest statistics. \\
${ }^{\text {b) }}$ From the net use of bark free wood.
\end{tabular}

As noted earlier, the main consumers of industrial roundwood in the EU are located in the north and central parts of the EU. Thus, our study investigates the indirect trade of industrial roundwood in the EU using the examples of Finland and Germany as countries with large consumption. In 2015, 74.3 $\mathrm{Mm}^{3}$ of roundwood was consumed in Finland. Of this, $64.7 \mathrm{Mm}^{3}$ was consumed as raw material in the forest industries. The remaining $9.6 \mathrm{Mm}^{3}$ (13\%) was turned into energy, mainly through burning of fuelwood in small-scale housing $\left(5.4 \mathrm{Mm}^{3}\right)$ and combustion of forest chips manufactured from stemwood $\left(4.2 \mathrm{Mm}^{3}\right)$ in heating and power plants. $12 \%$ of raw wood used in the forest industry was imported and $34 \%$ of this imported raw wood volume was turned to energy in 2015 (Figure 2). ${ }^{39}$ In 2004, these volumes were $23 \%$ and $39 \%$ respectively. ${ }^{30,40,41}$

Heinimo $^{30}$ presents a model in which wood streams that end up being used for energy purposes, raw material use and final products are calculated for the various branches of the forest industry in Finland. Branch specific consumption volumes of roundwood, imported pulp chips and indigenous woody products and production volumes of sawn timber and plywood available from forestry statistics ${ }^{18,39}$ are utilized as initial data. The Finnish forest industry uses by-products from roundwood use for in-house material and energy applications, as well as delivering some parts to other users such as district heating plants. Pulp chips are used in pulp mills as a raw material for pulp production. Sawdust is the major raw material for particleboard and fibreboard mills. The remaining sawdust is used as fuel for energy purposes. In practice, nearly all bark ends up being used for energy. According to modelling of wood streams in the Finnish forest industry, around $45 \%$ is eventually used for energy purposes, of which a large share of by-products from roundwood use are used for energy production purposes in chemical pulp mills $(77 \%)$ and in the sawmilling industry (14\%). From the viewpoint of international bioenergy trade streams, it is important to know how much imported raw wood is used for energy. Currently, in Finland, the chemical pulping industry consumes more roundwood than the sawmilling industry, and imports of roundwood are less ${ }^{39}$ than in 2004. ${ }^{30,40,41}$ Wood streams in the Finnish forestry are presented in Figure 2. 


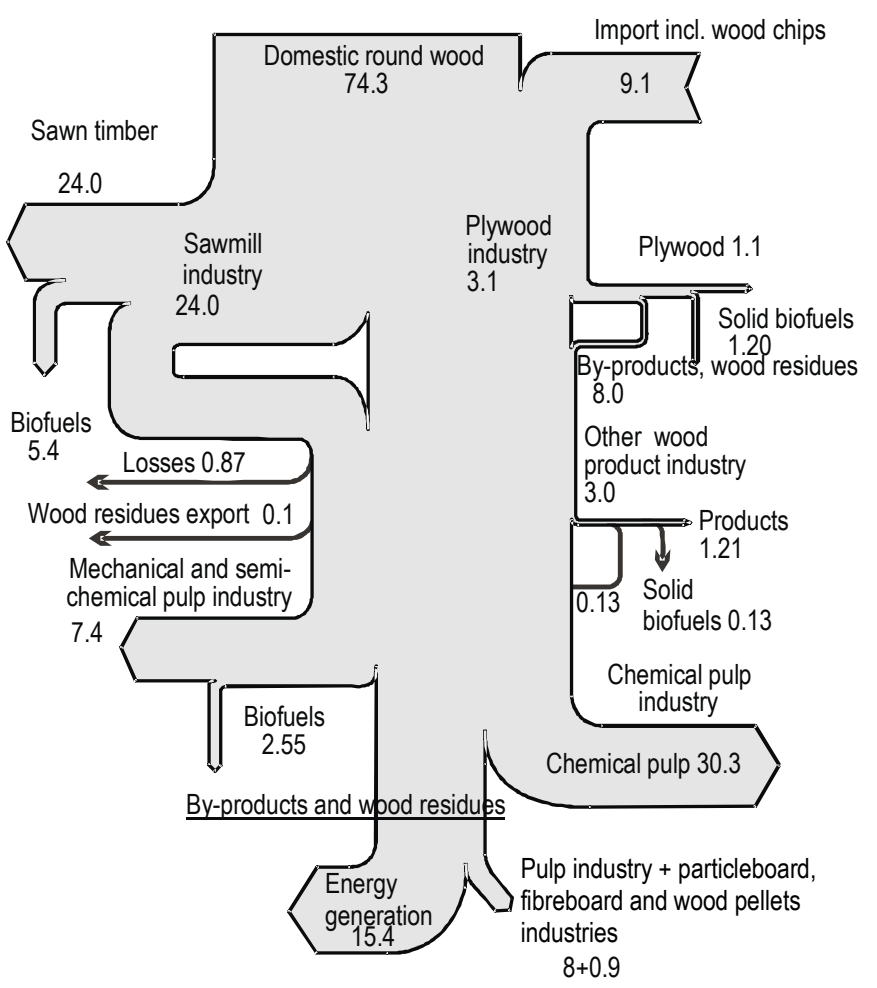

Figure 2. Wood streams in the Finnish forest industry in $2015\left(\text { in } \mathrm{Mm}^{3}\right)^{39}$

In a similar manner to the study by Heinimö, ${ }^{30}$ Bösch et al. ${ }^{20}$ discuss wood and paper flows for Germany. The study concluded that in 2010 the total flow of wood fibres through the German economy was $82.4 \mathrm{Mm}^{3}$, of which $76.6 \mathrm{Mm}^{3}$ were roundwood (sawlogs, pulpwood and fuelwood) and $5.8 \mathrm{Mm}^{3}$ landscape care wood. The main consumers of intermediate products were the paper industry with $38.3 \mathrm{Mm}^{3}$ (of which $13.1 \mathrm{Mm}^{3}$ were supplied by the pulp industry and $25.1 \mathrm{Mm}^{3}$ were in the form of recycled fibre i.e. recovered paper) and the sawmilling industry with $37.3 \mathrm{Mm}^{3}$. German forestry was the greatest supplier of intermediate products with $52.5 \mathrm{Mm}^{3}(30 \%)$. With regard to final use, the total volume was about 188 $\mathrm{Mm}^{3}$. The bulk of $46.6 \mathrm{Mm}^{3}$ were materials supplied by the paper industry. The paper industry exported $21.7 \mathrm{Mm}^{3}$. Wood fibres burnt for energy purposes had a total volume of almost $70 \mathrm{Mm}^{3}$. Of this volume, German forestry provided $28.3 \mathrm{Mm}^{3}$ or more than $40 \%$, which was used as fuelwood in private households and biomass power and heat plants. ${ }^{20}$

The conversion factor for used raw wood into end-products can vary in different countries of the EU-28. In Nordic countries, it reaches values up to $45 \%$ due to the large amount of chemical pulp production, which has lower wood conversion percentage from wood input streams into products than mechanical pulping (Table 2), while in Central Europe conversion can be higher due to the smaller share of chemical pulp wood manufacturing. Concerning final use of by-products for energy purposes, based on the Finnish and German examples, it is assumed in this study that roughly around $40-45 \%$ of industrial raw wood imported into EU28 ends up being burned for residential or industrial bioenergy. Indirect trade for energy purposes is presented in the estimated scale of international trade for industrial roundwood (section 4.2).

When considering China, the average conversion into biofuels is very different from the EU28. China consumes roundwood mostly as sawn timber from logs for construction $(30.4 \%)$, 
furniture material $(28.5 \%)$ and pulpwood $(41.0 \%){ }^{21}$ In 2014 , around $6.8 \mathrm{Mm}^{3}$ of all woody biomass was used for fuelwood production in the country. ${ }^{22}$ When considering products produced, after sawlogs, wood residues form the next largest volume in Europe, while in China, the second most produced product is plywood (Table 3).

Estimation of the volumes of imported industrial roundwood used for energy in China is difficult due to limited knowledge about the forest industry and by-products utilization in China. The vast majority of residues (which might be $40 \%$ of the volume entering the sawmill) are utilized for energy purposes. In many of the smaller sawmills, the by-products are removed by local residents and burnt locally. In metropolitan areas, some of the byproducts are collected and used for particleboard or medium-density fibreboard production. ${ }^{25}$ Table 3: Production of different products according to Faostat statistics, $2015^{13}$

\begin{tabular}{|lcc|}
\hline Production in $\mathbf{~ M m}^{\mathbf{3}}$ & China & EU-28 \\
\hline Sawlogs & 160 & 195 \\
\hline Pulpwood round and split, coniferous and non-coniferous & 57 & 146 \\
\hline Wood residues & 93 & 62 \\
\hline Sawnwood & 41 & 10 \\
\hline Plywood & 113 & 4 \\
\hline Wood fuel, coniferous (production) & 70 & 32 \\
\hline
\end{tabular}

The conversion efficiency from logs into sawn wood in Chinese sawmills is not high compared to, for example, Finland, where on average $46 \%$ of used roundwood, including bark, is converted into sawn timber. Plywood, which is the largest mechanical wood processing industry in the Chinese forest industry, ${ }^{22}$ has a lower wood conversion percentage from wood input stream (Table 2) products than sawnwood production. ${ }^{30}$ Thus, more byproducts are created in China compared, for example, to Finland. The comprehensive utilization rate (defined as the share of recovered raw wood material originating from a forest as the total input in Chinese forestry) is 65\% (some developed countries reach 90\%) and only $30 \%$ of by-products are utilized. ${ }^{23,42,43}$ According to experts, around $20-25 \%$ of the wood imported into China ends up being burned for domestic or industrial energy. ${ }^{25}$ However, when including the use of by-products which are not mentioned in official statistics, this percentage may be higher, around 25-35\%. Thus, we assumed that roughly around 30-35\% of wood imported into China can end up being used for energy purposes.

When discussing indirect trade evaluation, it is important to note that indirect trade data for roundwood are approximate. Firstly, national statistics do not differentiate between imported roundwood used as raw material and for energy. Moreover, for example, FAO statistics ${ }^{14}$ include a range of different products in the statistical categorization and present volumes for logs and pulp wood that can be assumed as relevant to use as raw material and, concurrently, fuel wood and waste wood. Secondly, there are often no statistics about the use of byproducts from different material applications. Thirdly, it is difficult to estimate the volume of by-products from imported roundwood and the volume from roundwood that was produced within the country. Finally, there is a large range of different applications for wood residues (by-products) e.g. particleboard production, and different applications have different utilization rates. 


\section{INTERNATIONAL TRADE}

\subsection{Exports and imports}

Figure 3 presents exports and imports of industrial wood chips and particles as well as industrial roundwood that are used for energy purposes. In our estimation, the conversion factor for indirect trade is $45 \%$, which since 2011 has dropped to $40 \%$, due to increased total imports of industrial roundwood into China and a reduction in the relative difference between EU and China industrial roundwood imports (Figure 1). In 2009, international forestry products trade decreased due to a reduction in worldwide production and consumption of industrial roundwood, as a result of the global financial crisis, and due to the introduction of export duties on roundwood in Russia. ${ }^{44}$ Export and import of fuel wood and charcoal are presented in Figure 4. Charcoal trade has seen consistent growth because of stable increase in production and export by African countries. However, this trend may change due to sustainability concerns, because production of charcoal plays a role in forest depletion. 5-12 tons of wood is required for the production of 1 ton of wood-based charcoal. ${ }^{24}$

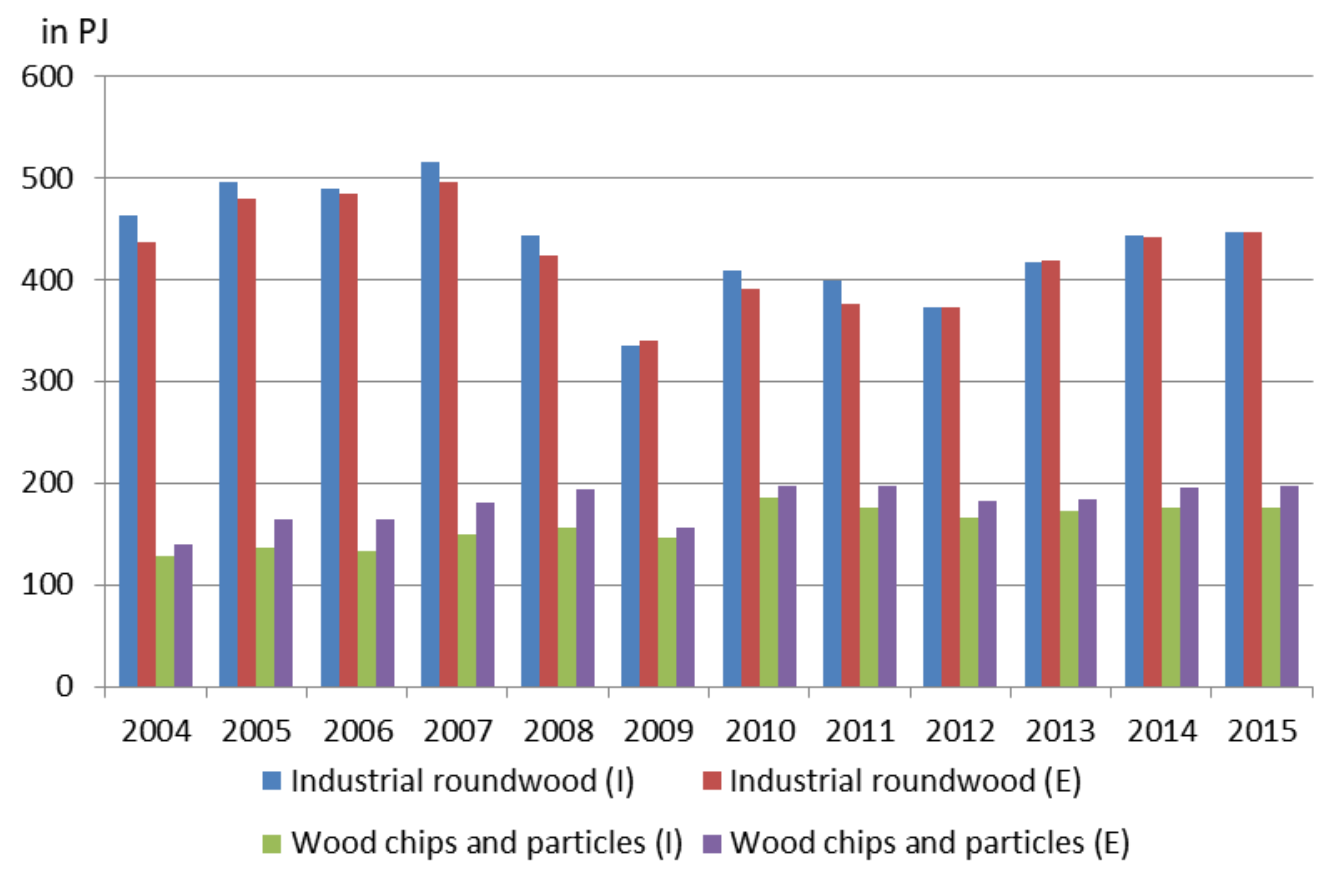

Figure 3. Total exports (E) and imports (I) of studied products as indirect trade globally. ${ }^{13,15}$ 


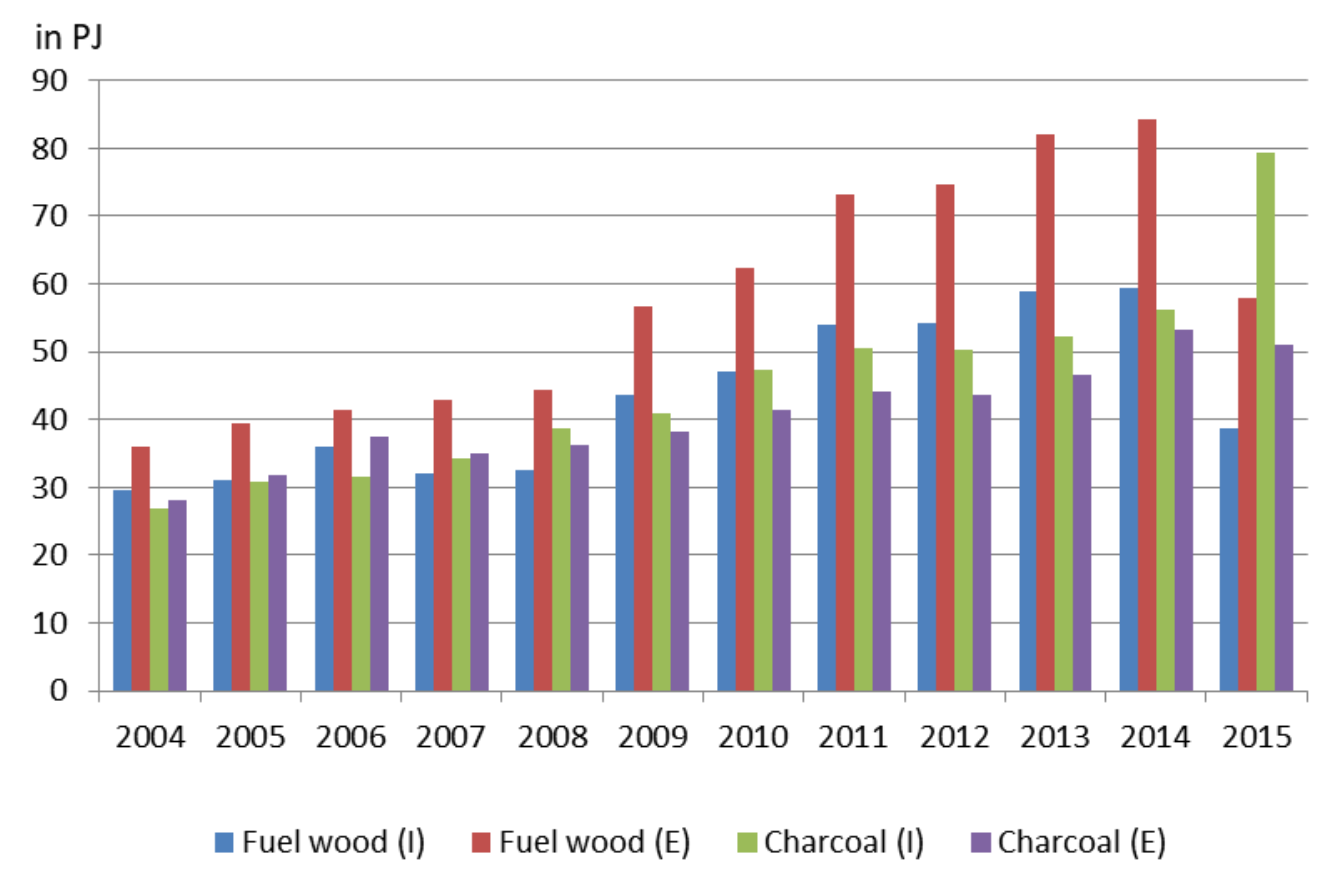

Figure 4. Total imports (I) and exports (E) of studied solid biofuels globally excluding wood pellets. ${ }^{13,15,41}$ (For wood pellets see Figure 5.)

The global trade in fuel wood increased until 2014, because international trade in wood fuel was strong in Europe, Southeast Asia and North America. In 2015, it decreased due to the lower fossil fuels price. Generally, international trade in fuel wood (Figure 4) is much smaller than trade in industrial roundwood (Figure 3), at least as regards trade recorded in official statistics. Fuel wood is mainly traded over short distances across borders, and this trade also often occurs in the informal economy. Lamers et al. ${ }^{3}$ note that fuel wood has practically no flowability and requires special handling in bulk transport. The share of charcoal is larger than the share of fuel wood, which can be explained by charcoal, in addition to being used for heating and cooking (including barbeques in developed countries) being widely used in the chemical and pig iron industries. ${ }^{44}$

When considering direct trade of fuel wood, wood pellets are the most traded product. During the last 5 years, trade in wood pellets has increased significantly, and wood pellets have become the most traded solid biofuel in the world (Figure 5). This development may be explained by the advantageous characteristics of wood pellets compared with other solid biofuels. The low moisture content and relatively high calorific volume (about $17 \mathrm{MJ} / \mathrm{kg}$ ) of wood pellets, and easy handling during transportation and storage, without significant loss of dry matter, make wood pellets profitable for long distance transportation. ${ }^{13,38}$ 


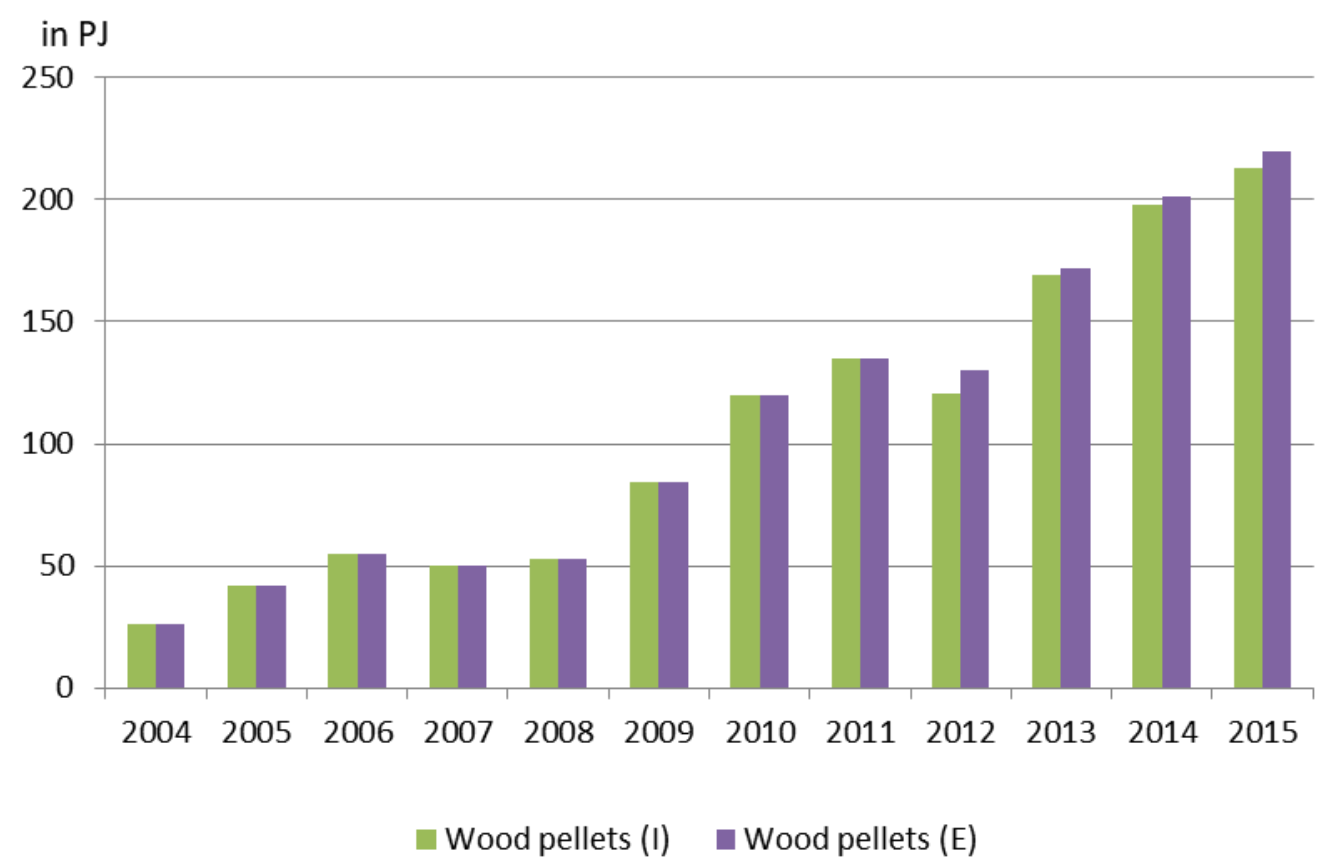

Figure 5. Total exports (E) and imports (I) of wood pellets globally. ${ }^{15,45}$

Figure 6 shows exports and imports of liquid biofuels, including palm oil, used for energy purposes only. Bioethanol and biodiesel trade peaked in 2012-2013, since when trade has decreased. In 2013-2015, global biodiesel, bioethanol and palm oil trade decreased mainly due to new rules established by the European Commission to reduce indirect land use change, which came into force in 2015, and which reduced demand for food product-based first generation biofuels ${ }^{32}$ and introduced sustainability criteria for soy and palm oil.

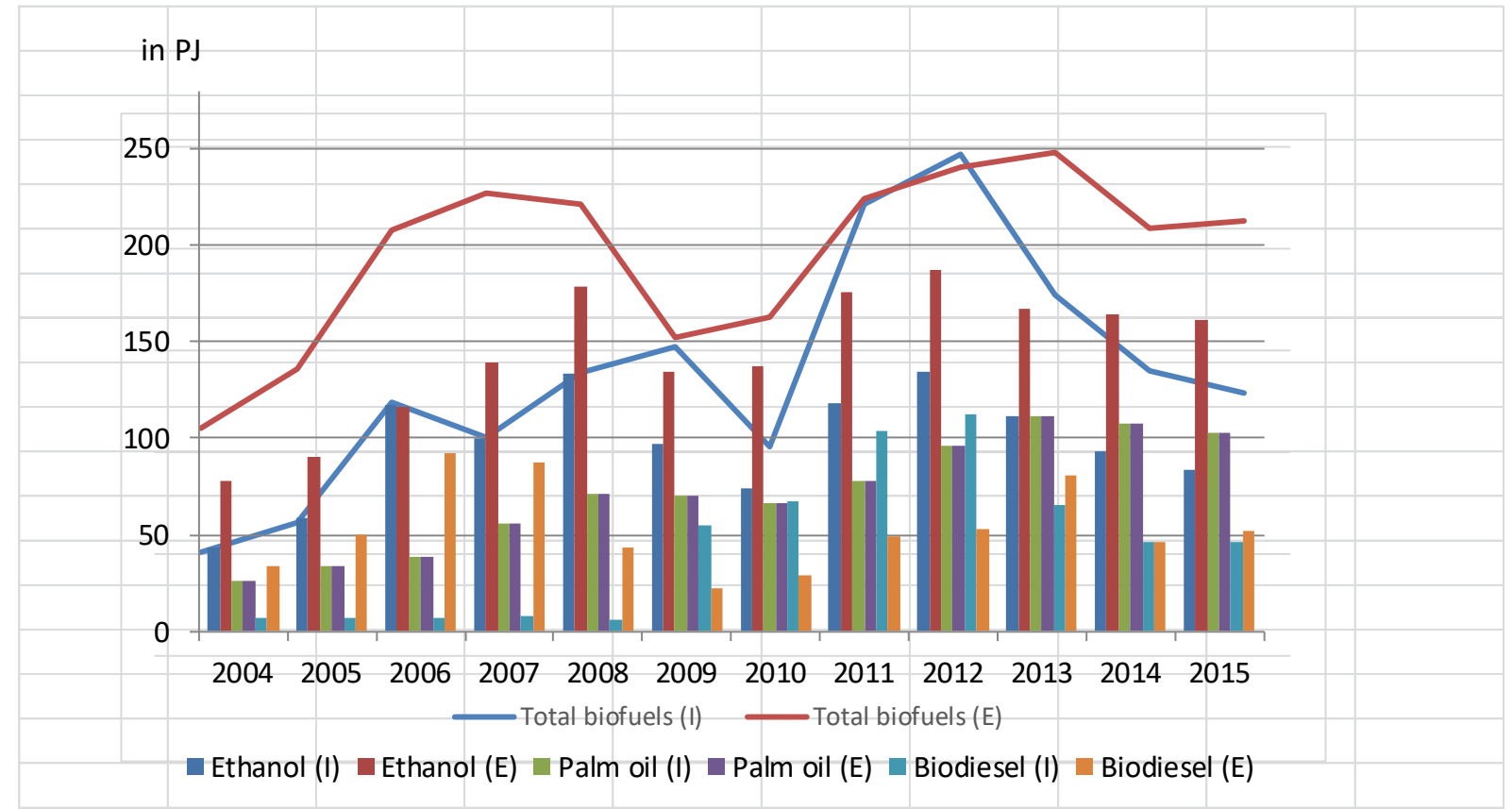

Figure 6. Total exports (E) and imports (I) of studied liquid biofuels and palm oil for energy use globally. ${ }^{13,15,16}$ 


\subsection{Estimated scale of international trade in studied products}

Table 4 shows the estimated scale of international trade of the studied products, which is a key result of the study. The estimated uncertainty of the trade volumes, which is calculated based on the difference between export and import volumes, is presented in brackets (Table 4). As can be seen from Section 4.1, changes in trade volumes for almost all studied products can be explained by changes in production and/or traded volumes of the main exporter and importer countries. For example, global ethanol market development depends on ethanol production in the USA and Brazil, because they account for about $75 \%$ of the world's ethanol production and are the main global exporters, and on imports into the EU as the main bioethanol importer. ${ }^{16,34}$

Table 4: Estimated scale of international trade of studied product in 2004-2015 in PJ (Derived from world import and import numbers). Ethanol, ${ }^{15,16}$ roundwood and wood chips and particles, ${ }^{13}$ wood pellets, ${ }^{15,31}$ charcoal, ${ }^{15}$ biodiesel, ${ }^{15,16}$ ethanol, ${ }^{15,16}$ and palm oil. ${ }^{15,31}$ Values in brackets are the estimated uncertainty of the volumes.

\begin{tabular}{|c|c|c|c|c|c|c|c|}
\hline Year / product & 2004 & 2008 & 2011 & 2012 & 2013 & 2014 & 2015 \\
\hline Indirect trade (end up for energy): $a$ & $585( \pm 16)$ & $610( \pm 23)$ & $575( \pm 14)$ & $550( \pm 10)$ & $650( \pm 5)$ & $625( \pm 10)$ & $640( \pm 10)$ \\
\hline - Industrial roundwood $a, b$ & $450( \pm 15)$ & $435( \pm 10)$ & $390( \pm 10)$ & $375( \pm 1)$ & $470( \pm 1)$ & $440( \pm 1)$ & $450( \pm 0)$ \\
\hline - Wood chips and particles $a, c$ & $135( \pm 5)$ & $175( \pm 20)$ & $185( \pm 10)$ & $175( \pm 10)$ & $180( \pm 5)$ & $185( \pm 10)$ & $190( \pm 10)$ \\
\hline Direct trade: & $200( \pm 25)$ & $385( \pm 32)$ & $560( \pm 44)$ & $580( \pm 44)$ & $615( \pm 32)$ & $610( \pm 37)$ & $610( \pm 44)$ \\
\hline - Charcoald & $30( \pm 1)$ & $40( \pm 1)$ & $50( \pm 5)$ & $50( \pm 5)$ & $50( \pm 5)$ & $55( \pm 1)$ & $65( \pm 15)$ \\
\hline - Fuel wood $e$ & $35( \pm 5)$ & $40( \pm 5)$ & $65( \pm 10)$ & $65( \pm 10)$ & $70( \pm 10)$ & $70( \pm 10)$ & $50( \pm 10)$ \\
\hline - Wood pellets $f$ & $30( \pm 0)$ & $55( \pm 0)$ & $135( \pm 0)$ & $125( \pm 5)$ & $170( \pm 1)$ & $200( \pm 1)$ & $220( \pm 5)$ \\
\hline - Biodiesel $g$ & $20( \pm 15)$ & $25( \pm 20)$ & $80( \pm 30)$ & $85( \pm 30)$ & $75( \pm 10)$ & $45( \pm 1)$ & $50( \pm 5)$ \\
\hline - Ethanol as biofuel $h$ & $60( \pm 20)$ & $155( \pm 25)$ & $150( \pm 30)$ & $160( \pm 30)$ & $140( \pm 30)$ & $130( \pm 35)$ & $120( \pm 40)$ \\
\hline Palm oil for bioenergy use $i$ & $25( \pm 0)$ & $70( \pm 0)$ & $80( \pm 0)$ & $95( \pm 0)$ & $110( \pm 0)$ & $110( \pm 0)$ & $105( \pm 0)$ \\
\hline Total (end up for energy) & $785( \pm 29)$ & $995( \pm 39)$ & $135( \pm 46)$ & $130( \pm 45)$ & $1266( \pm 33)$ & $1235( \pm 39)$ & $1250( \pm 45)$ \\
\hline
\end{tabular}

The values in Table 4 include the following assumptions and generalizations, which are marked (a)-(i) in the table:

(a) The conversion factor is assumed as $45 \%$ prior to 2011 and $40 \%$ post-2011 because of 40-45\% average conversion into biofuels in EU and 30-35\% for China (for details see Section 2 and 3.1).

(b) Roundwood in FAO's statistics ${ }^{13}$ is without bark; therefore, $10 \%$ bark was added based on general estimation from. ${ }^{30}$ Other assumptions include average density of $0.8 \mathrm{t} / \mathrm{m}^{3}$ and calorific value of $9.4 \mathrm{GJ} / \mathrm{t}$ based on. ${ }^{30}$

(c) Average density of $0.8 \mathrm{t} / \mathrm{m}^{3}, 40-45 \%$ average conversion into biofuels and caloric value of $9.4 \mathrm{GJ} / \mathrm{t}$ are assumed.

(d) Calorific value of $22 \mathrm{GJ} / \mathrm{t}$ is assumed.

(e) Density and calorific value of $0.7 \mathrm{t} / \mathrm{m}^{3}$ and $13 \mathrm{GJ} / \mathrm{t}$ are assumed.

(f) Based on 2004 22 and 2008..$^{31}$ For 2004 and 2008, cross trade $=E U$ intra trade + EU extra trade + Canadian exports to the USA + Canadian exports to other countries (excluding EU-27). For 20122015, data source ${ }^{15}$ and export/import volumes are used. Density and calorific value of $0.8 \mathrm{t} / \mathrm{m}^{3}$ and $17.5 \mathrm{GJ} / \mathrm{t}$ and a conversion rate of 0.8 are assumed.

(g) Data source. ${ }^{15}$ Density and calorific value of $0.88 \mathrm{t} / \mathrm{m}^{3}$ and $37.8 \mathrm{GJ} / \mathrm{t}$ are assumed.

(h) Data sources. ${ }^{16}$ Density and calorific value of $0.79 \mathrm{t} / \mathrm{m}^{3}$ and $26.8 \mathrm{GJ} / \mathrm{t}$ are assumed.

(i) Years 2004. ${ }^{31,38}$ Years 2008-2015. ${ }^{33}$ 
During 2004-2015, world production of most of the studied products increased, especially production of solid and liquid biofuels. Interestingly, volumes of direct trade started to approach those of indirect trade in the last 5 years of the period studied. Figure 7 presents a comparison of direct and indirect trade for energy based on Table 4. Compared with previous studies, this is a noteworthy result: indirect trade remained broadly stable, whereas direct trade steadily increased.

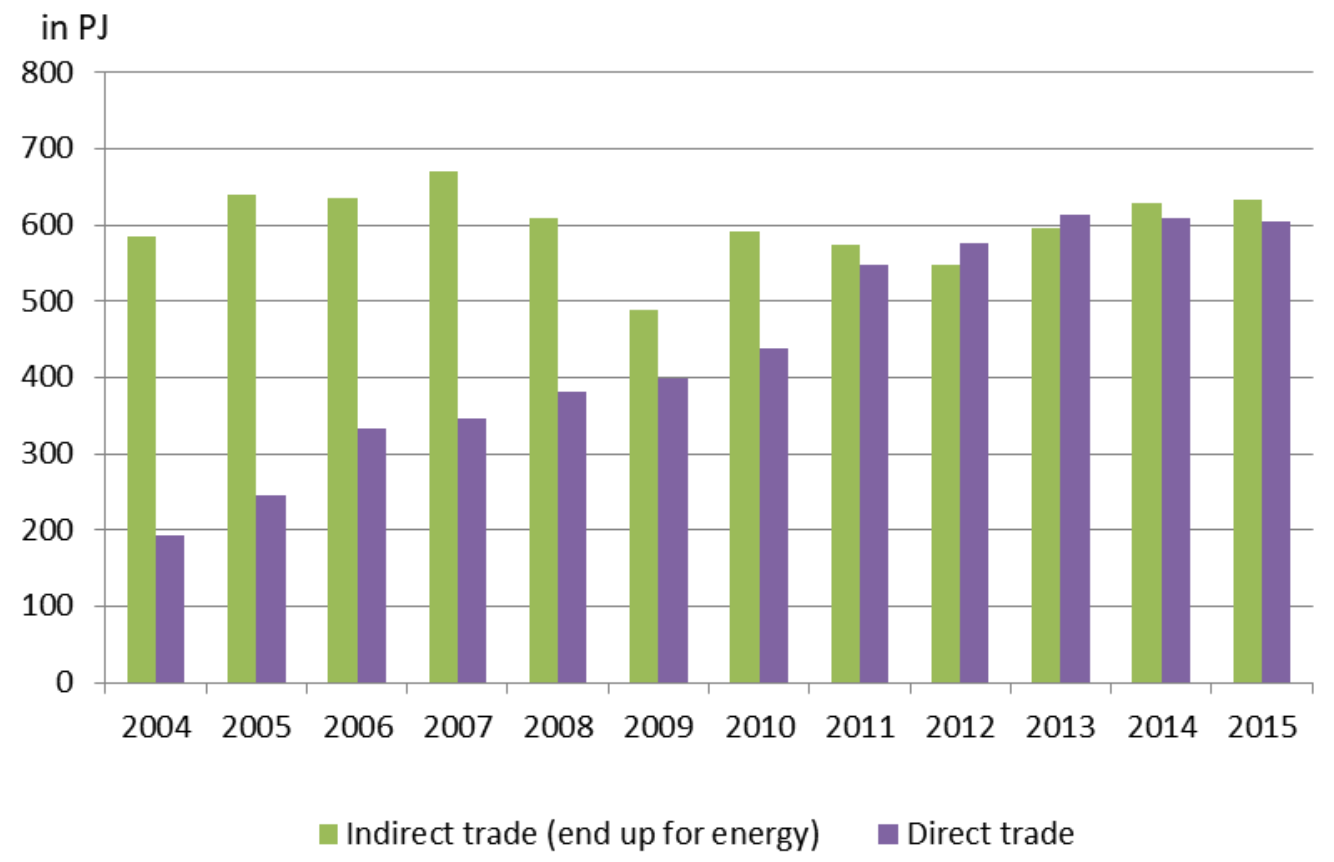

Figure 7. Comparison of direct and indirect global trade for energy based on Table 4.

\section{DISCUSSION}

Although the evaluation method of previous studies was extended, with the aim of improving rigor and reliability, the method presented in this study is not without drawbacks.

Firstly, indirect trade evaluation is one of the main challenges for this kind of research. The study demonstrates that accurate estimation of a universal conversion efficiency (as done for Finland) for raw wood imported into China seems unattainable due to a lack of reliable information about key aspects such as the branch of the forest industry where the imported wood is consumed. Volumes of by-products and the nature of their utilization seem very unclear for China. China has large volumes of forest residues from roundwood use, but how such residues are used is not well known. The conversion factor for China presented in this work has to be considered as rather approximate due to limited knowledge about Chinese forestry wood streams. The information utilized in the review was gathered mainly from the literature and the internet, and partly from expert opinions, which showed some divergence regarding similar issues.

Secondly, despite the importance of the international trade in biomass and the large amount of research in the field, there is no comprehensive available data for biomass trade volumes. Furthermore, differences in data interpretation and in values from different sources create uncertainties. For example, Chinese statistics and FAOSTAT recorded different imported 
volumes of industrial roundwood. Additionally, data in Trade Map is slightly different from Eurostat regarding wood pellets exports and imports in the EU-28. The difference between total exports and imports for biofuels such as ethanol and biodiesel creates additional uncertainties about data reliability.

Thirdly, traded biomass can have several applications, and final uses of traded solid and liquid biofuels are not easily evaluated. For example, palm oil can be used both for biodiesel and in the food industry, and ethanol can be used for transport fuel and as a feedstock for the chemical industry.

Finally, the international biomass trade is complex and involves many different aspects such as logistical issues and policy regulations that are outside the scope of the study. The reasons for the trends found in this work and possible impacts on future biomass markets are not addressed, as the focus is on evaluation of trade volumes rather than study of factors driving development.

The above limitations must be borne in mind when considering the results of the study. Indirect trade volumes depend greatly on the applied conversion factor, which was approximated. Use of a larger conversion factor would give larger volumes of indirect trade. Thus, the presented volumes of indirect trade are very sensitive to the assumed conversion factor. The estimation of direct trade seems more reliable, but is, however, limited by data availability and data variation.

The development of international trade and international markets in biomass for energy production is at a relatively early stage. The study focuses on trade volumes and does not consider production data and agricultural products; however, most agricultural products have much larger volumes of production and trade than solid and liquid biofuels. As an indicator of relative market size, the trade of wheat ${ }^{16}$ and soybeans ${ }^{33}$ was about 150 and 130 million tons respectively in 2015. Paper and paperboard trade with about 110 million tons ${ }^{13}$ is larger than, for example, trade in wood pellets with 16 million tons (2015).

The study shows that wood pellets and ethanol are typical examples of biofuels that are widely traded and have commodity type markets. ${ }^{46}$ The other studied products do not have the same commodity status on world markets. Some emerging biomass streams such as torrefied biomass, bio jet fuel, biochar and cooking oil are not included in the study because of their minor current contribution to world bioenergy trade volumes. However, they have potential for further development, in particular, torrefied biomass. ${ }^{47}$

\section{CONCLUSION}

The aim of the present research was to provide an updated quantitative evaluation of direct and indirect international trade in biomass for energy purposes, showing exports and imports, as well as providing an estimation of the scale of international trade in biomass for energy. Additionally, the study examined a number of methodological issues in evaluation of global biomass trade. This study found that during the studied period of 12 years, the international trade in biomass for energy almost doubled, from around 800 PJ (2004) to 1300 PJ (2015). This is about $5 \%$ of total bioenergy use globally ${ }^{48}$ in 2015 . Indirect trade remained stable and direct trade increased from about 200 PJ (2004) to 600 PJ (2015). Thus, in the last 5 years of the period studied, direct trade of biomass for energy started to approach the volume of indirect trade. Currently, wood pellets are the most traded commodity. Wood pellets showed 
significant growth, attaining $25 \%$ of total direct biomass trade for energy purposes. The trade in ethanol and biodiesel peaked in 2013 and then decreased. Trade in palm oil for energy purposes increased in the last decade of the period studied due to greater usage of palm oil for energy purposes in the EU.

International biomass markets are developing rapidly, and trade in biomass for energy will continue to be an important aspect of global bioenergy development. Although the method of previous studies was extended and refined in this work, it is clear that the methodology used for international biomass trade evaluation is sensitive to a number of factors, especially as regards indirect trade, and limited by data availability. Reliable bioenergy data is very important in international biomass trade estimation, and it is recommended that increased efforts be made to collect and publish coherent bioenergy trade statistics.

This research extends knowledge of international trade in biomass and can be useful for the creation of scenarios of future developments in biomass markets. Further research should focus on determining the possibility and potential of trade in biomass waste and its final applications. Examination of the impact of policy developments and legislation as well as the impact of sustainability certification on biomass trade can be an interesting subject for future research. Currently, insufficient detailed data is available for China. Development and application of a forest industry wood stream model similar to that previously presented for Finland may provide useful insights and enable more accurate estimation of a universal conversion efficiency value for imported raw wood and energy use in China.

\section{ACKNOWLEDGEMENTS}

This work was carried out for the IEA Bioenergy Task 40 (Sustainable biomass markets and international trade to support the biobased economy), "Update study of International energy biomass trade". We would like to thank Beysin Tekinel from Lappeenranta University of Technology for providing the data collection at the beginning of the study. We would also like to thank Thuy Mai-Moulin, Ric Hoefnagels, Hui Yue, Sierk de Jong, Maria Joao Ferreira Dos Santos, and Li Shen from the Copernicus Institute of Sustainable Development (Utrecht University) for valuable comments. The authors would like to acknowledge members of IEA Bioenergy Task 40 for their insights into global biomass markets operation. We would like to thank Peter Jones (LUT) for valuable comments. 


\section{REFERENCES}

[1] Ellabban O, Abu-Rub H, Blaabjerg F, Renewable energy resources: Current status, future prospects and their enabling technology. Renewable and Sustainable Energy Reviews 397:48-764 (2014).

[2] Heinimö J and Junginger M, Production and trading of biomass for energy - An overview of the global status. $15^{\text {th }}$ European Biomass Conference and Exhibition, Berlin, Germany (2007).

[3] Lamers P, Hamelinck C, Junginger M and Faaij APC, International bioenergy trade - a review of past developments in the solid biofuels market. Renewable and Sustainable Energy Review 16(5):3176-3199 (2012).

[4] Lamers P, Hamelinck C, Junginger M and Faaij APC, International bioenergy trade - a review of past developments in the liquid biofuels market. Renewable and Sustainable Energy Review 15:2655-2676 (2011).

[5] Goh CS, Junginger M, Cocchi M, Marchal D, Thrän D, Hennig, C et al., Wood pellet market and trade: A global perspective. Biofuels Bioprod Bioref.7:24-42 (2013).

[6] Goh CS, Junginger M and Faaij APC, Monitoring sustainable biomass flows: General methodology development. Biofuels Bioprod Bioref 8:83-102 (2014).

[7] IEA Task 40. [Online] (2017). Available at http://task40.ieabioenergy.com/ [accessed 25 March 2017].

[8] Lamers P, Hoefnagels R, Junginger M, Hamelinck C and Faaij APC, Global solid biomass trade for energy by 2020: An assessment of potential import streams and supply costs to north-west Europe under different sustainability constraints. GCB Bioenergy 7(4): 618634 (2014).

[9] Matzenberger J, Kranzl L, Tromborg E, Junginger M, Daioglou V, Goh CS et al., Future perspectives of international bioenergy trade. Renewable and Sustainable Energy Review 43:926-941 (2015).

[10] Hoefnagels R, Resch G, Junginger M and Faaij APC, International and domestic uses of solid biofuels under different renewable energy support scenarios in the European Union. Applied Energy 131:139-157 (2014).

[11] Proskurina S, Junginger M, Heinimö J and Vakkilainen E, Global biomass trade for energy: Part 2 - production and trade streams. Biofuel Bioprod Bioref (in this issue).

[12] FAO, Wood fuels handbook. Food and agriculture organization of the United Nations. Pristina (2015).

[13] Faostat, Food and agriculture organization of the United Nations Statistics Division, [Online] (2015). Available at: http://faostat3.fao.org/browse/F/*/E [accessed 25 July 2016].

[14] FAO, Enhancing sustainability and efficiency of woodfuel production and consumption. African forestry and wildlife commission, Nairobi: Food and Agriculture Organization of the United Nations, pp. 1-1 (2016).

[15] ITC, List of supplying markets for a product imported by country. TRADE MAP International Trade Statistics, (2016). Available at: http://www.trademap.org/tradestat/Country_SelProductCountry_TS.aspx [accessed 22 July 2016]. 
[16] OECD, OECD-FAO agricultural outlook 2015-2024: OECD-FAO agricultural outlook 2015-2024, by commodity. OECD.stat (2016).

[17] Eurostat, 2016. Forestry statistic. [Online] (2016). Available at: http://ec.europa.eu/eurostat/statistics-explained/index.php/Forestry_statistics [accessed 8 December 2016].

[18] Finnish forest statistic, 2013 [Online] (2013) Available at: http://www.stat.fi/til/mettp/2013/mettp_2013_2014-12-22_tie_001_en.html [accessed 18 March 2017].

[19] Schipfer F, Kranzl L, Olsson O and Lamers P. The European Wood Pellet Market for small-scale heating, data availability, price developments and drivers for trade. IEA Bioenergy Task 40, Sustainable Biomass Markets and International Trade to support the biobased economy (2017). In press.

[20] Bösch M, Jochem D, Weimar H and Dieter M, Physical input-output accounting of the wood and paper flow in Germany. Resources, Conservation and Recycling 94:99-109 (2015).

[21] Annual Statistics Report of China Forestry 2003-2013. Available at: http://www.forestry.gov.cn/main/225/content-763186.html (In Chinese) [accessed 8 December 2016].

[22] State Forestry Administration of China. China Forestry Statistical Yearbook 2011 [Online]. China Forestry Publishing House. Available at: http://www.stats.gov.cn/tjsj/ndsj/2011/indexeh.htm (In Chinese) [last accessed 8 December 2016].

[23] Qingfu X, Research on Estimation of Exploitation Utilization Technology and Optimization of Product Mix of Forestry Bioenergy. Harbin, Northeast Forestry University, (2007).

[24] TFT, Charcoal TFT research [Online] (2015). Available at: http://www.tftearth.org/wp-content/uploads/2015/05/TFT-charcoal-research.pdf [accessed 8 June 2017].

[25] Opinion of Operations Director from Global Timber Forum, 2016.

[26] Opinions of members of IEA Task 40

[27] Opinions of participants in internal meetings in Copernicus Institute of Sustainable Development, Utrecht University.

[28] Allen BR, Keegan D and Elbersen B, Biomass and bioenergy in the wider land-use context of the European Union. Biofuel Bioprod Bioref 7:207-216 (2013).

[29] Proskurina S, Alakangas E, Heinimö J, Mikkilä M and Vakkilainen E, A survey analysis of the wood pellet industry in Finland: Future perspectives. Energy 95:64-77 (2017).

[30] Heinimö J, Methodological aspects on international biofuels trade: international streams and trade of solid and liquid biofuels in Finland. Biomass and Bioenergy 32(8):702-716 (2008).

[31] Lamers P, Junginger M, Hamelinck C and Faija APC, Developments in international solid biofuel trade-An analysis of volumes, policies, and market factors. Renewable and Sustainable Energy Review, 16(5):3176-3199 (2012). 
[32] European commission, Energy, Land use change, [Online] (2015). Available at: https://ec.europa.eu/energy/en/topics/renewable-energy/biofuels/land-use-change [accessed 18 November 2016].

[33] USDA, USDA Foreign Agricultural Service, in United States Department of Agriculture - Foreign Agricultural Service. [Online] (2016). Available at: http://www.fas.usda.gov/data/search?f[0]=field_report_type\%3AWorld\%20Production\% 2C\%20Markets\%2C\%20and\%20Trade\%20Reports [accessed 25 July 2016].

[34] ITC, Frequently asked questions, [Online]. 1999. Available at: http://www.trademap.org/stFAQ.aspx\#li_Answer2_3 [last accessed 22 July 2016].

[35] Transport and Environment. Cars and trucks burn almost half palm oil used in Europe, (2016).

[36] Schleifer F. Private Governance Undermined: India and the Roundtable on Sustainable Palm Oil. Global Environmental politics, 16(1):38-58 (2016).

[37] WWF, The World Wide Fund for Nature. China 2012. The Journey Towards Sustainable Palm Oil.

[38] Heinimö $\mathrm{J}$ and Junginger $\mathrm{M}$, Production and trading of biomass for energy - An overview of the global status. Biomass and Bioenergy 33(9):1310-1320 (2009).

[39] LUKE, Forest industries' wood consumption, [Online] (2016). Available at: http://stat.luke.fi/en/wood-consumption [last accessed 18 December 2016].

[40] Finnsh Forest Industries Federation. Paperia ja Puuta. Ympäristönsuojelun vuosikirja 2005. Tilastot vuodelta 2004, 2005, 28pp.

[41] Aarne M, Peltola A, editors. Metsa“ tilastollinen vuosikirja 2005. (The Finnish statistical yearbook of forestry). Finnish Forest Research Institute; 2005. p. 396.

[42] Lin H, Study on Preparation Process of Sleeper Composites Made from Wood Residue. Harbin, Northeast Forestry University, (2011).

[43] Yang X, Xiangzhe DU, Yingjie QI, Lei MA and Gang ZHENG, Utilization of Wood Processing Residues. China Forest Products Industry 5:013 (2015).

[44] Lamers P, Marchal D, Heinimö J, Steierer F, Chapter 3 Global woody biomass trade foe energy. In: Junginger M, Goh CS, Faaij APC, International bioenergy trade, History status \& outlook on securing sustainable bioenergy supply, demand and markets, 2014.

[45] Thrän D, Peetz D, Schaubach K et al., Global wood pellet industry and trade study 2017. IEA Bioenergy: Task 40 [Online] (2017). Available at: http://task40.ieabioenergy.com/wp-content/uploads/2013/09/IEA-Wood-PelletStudy_final-july-2017.pdf [accessed 8 September 2017].

[46] Proskurina S, Rimppi H, Heinimö J, Hansson J, Orlov A, Raghu K et al., Logistical, economic, environmental and regulatory conditions for future wood pellet transportation by sea to Europe: The case of Northwest Russian seaports. Renewable and Sustainable Energy Review 56:38-50 (2016).

[47] Proskurina S, Heinimö J, Schipfer F, Vakkilainen E, Biomass for industrial applications: The role of torrefaction. Renewable Energy 111:265-274 (2017).

[48] IEA, World energy balances: Overview. p.3 [Online] (2017). Available at: http://www.iea.org/publications/freepublications/publication/WorldEnergyBalances2017 Overview.pdf [accessed 8 September 2017]. 